\title{
Growth Status of Unorganised Food Processing Enterprises in India
}

\section{Akash Dandapat, Soumita Dasgupta and Pinaki Das*}

Department of Economics, Vidyasagar University, West Bengal, India

*Corresponding author: pdasvu@mail.vidyasagar.ac.in

\begin{abstract}
This paper examines the growth status of unorganised food processing enterprises (UFPEs) in India based on the latest NSSO Unit level data of the $67^{\text {th }}(2010-11)$ and $73^{\text {rd }}(2015-16)$ rounds. Food processing is an important activity in unorganised manufacturing sector in India. UFPEs occupied 12\% share in unorganised manufacturing sector in 2015-16. It is found that the number of UFPEs and their employment increased significantly during 2010-11 to 2015-16. Among eight different activities of UFPEs, grain mill activities occupied the largest share in respect of enterprise as well as employment. Labour productivity of urban located UFPEs was higher in all activities except animal feeds and processing of fruits \& vegetables. Whereas among all activities, the average labour productivity was higher in animal feeds, processing of fish and edible oil product enterprises. Among UFPEs the percentage shares of expanding and stagnating enterprises were $32.2 \%$ and $42.1 \%$ respectively in 2010-11. In 2015-16, the share of expanding and stagnating enterprises reduced marginally. The multinomial logit regression of growth status shows that the type of an enterprise, its nature, availability of loan, maintenance of accountant and the rate of profit significantly affects the growth status of an enterprise.
\end{abstract}

Keywords: Unorganised, Food Processing, Enterprise, Employment, Status of Growth

Food processing activity is one of most important activity among all non-farm activities. This activity is important in respect of generation of employment and output. It is also important for the development of agriculture. Food processing enterprises take the outputs of agriculture products and use these as inputs. So, these enterprises create demand of agriculture outputs in one hand and generate non-farm employment opportunities on the other. Among several agricultural/ food items produced in India only less than 10\% are processed. In the coming years demand for processed food items is set to increase in India which will provide opportunities for greater value addition, lower wastages and alternative employment opportunities. Analysis of corporate data shows food processing firms have been profitable, but the value addition component needs to improve significantly (Dhanya et al. 2020). Industrial development of any country not only depends on innovation and capital outflow, but availability of raw materials and adequate physical infrastructural facilities are also required. Agriculture sector belongs to one of such major raw material providing sector which provides raw materials in different big industries like paper, sugar, textile, fertilizers, chemical, edible oil, etc., Problem of poverty, unemployment and inequality can be resolved to a large extent with these agro-based

How to cite this article: Dandapat, A., Dasgupta, S. and Das, P. (2020). Growth Status of Unorganised Food Processing Enterprises in India. Int. J. Soc. Sci., 9(04): 291-299.

Source of Support: None; Conflict of Interest: None 
industries in India by significantly contributing to the overall development of the economy through efficient utilization of the local raw materials which consequently increase the gainful employment opportunities to poor people mainly landless, marginal and small farmers. (Paramasivan and Pasupati, 2016). Venkatesh et al. (2017) found a rapid growth in the number of processing firms in the study region during 2000s. The growth was fuelled by export demand, assured supply of raw material and Government's policy incentives. On an average, the cultivation cost of mango was ₹ 1.56 lakh/ha while the cost of production was ₹ 8.29/kg and farmers received net income of ₹ 1.34 lakh/ha. The estimated cost of mango processing was to be $₹ 7 / \mathrm{kg}$. More than $90 \%$ farmers were linked with the processors either directly or through local contractors and for this sector an oral agreement was the common form of institutional mechanism. In view of its large potential for growth, agro-based industry is regarded as the sunrise sector of the Indian economy and likely to have socio-economic impact specifically on employment and income generation. Some estimates suggest that in developed countries, directly or indirectly approximately $14 \%$ of the total work force is engaged in agro-processing sector. However, in India, employment participation in this sector is only about $3 \%$ of the work force which enlighten its underdeveloped state and vast untapped potential for employment (Dhiman and Rani, 2011). Kaur and Kaur (2016) analysed efficiency and productivity changes in 50 firms of food manufacturing industry during the period1988 to 2011 in which firms were included from different sectors of food processing mainly Sugar, Bakery Products, Beer \&Alcohol, Dairy Products, Processed Food and Vegetable Oil. To compute the change in Malmquist Total Factor Productivity (TFP), a nonparametric Data Envelopment Analysis (DEA) approach is used which has been further decomposed into efficiency and technical change. The paper gave suggestions that can be used by policy makers and food processors in making decisions regarding various technical and managerial aspects to improve productivity and efficiency based on the findings. S\&T capability, employment and skills opportunities of food processing industry in India is analysed by Rais et al. (2013). The employment generation power of this sector is immense, but the industry is not working at its potential level. The educational qualification of workers of this sector were very low. It was found that educational level of $80 \%$ workers were below $10^{\text {th }}$ standard. Government had taken various steps to develop this sector but these were not much encouraging. Thus, there is an urgency of serious involvement of the state in S\&T capability, infrastructure support and skillsin order to develop food processing sector. Agro industries in India is important due to their role in the development of rural farmers. To know the real potential and challenges faced by them, features and constraints were examined. Various models like institutional and organizational evaluated to know performance and contribution in development of rural farmers. Bhosale (2016) suggested some policy and managerial implications. Whereas Mohan and Jayachandra (2018) found various marketing problems of Rice mill industry in Patiala district. The problems were lack of financial support, poor marketing channel, high degree of breakdown of finished products and lack of research lab for quality control. As there is an opportunity of development and if this sector develops properly then Punjab may be a major player at the global level for supply and marketing of processed food for billion plus mouths to feed. Rais (2014) emphasized the potential of India's north-eastern region (NER). According to him NER is endowed with various food products. So, it has the potential to make itself a sunrise zone for food processing businesses. He further observed that simple value addition like packaging, sorting and cleaning could increase income of farmers by $42.8 \%$ per $\mathrm{kg}$. Lack of infrastructure like bad connectivity with big markets, lack of supply chain are obstacles of the development of food processing sector in this region.

From the brief of existing literature, we have found that the status of growth of UFPEs was not adequately analysed. Existing studies also deficient to analyse the status of growth, employment and other characteristics across activities of UFPEs. In this brief background present study sets the following objectives:

1. To analyse the characteristics and employability of UFPEs.

2. To examine the factors that explain the status of growth of UFPEs. 
Rest of the work is divided into five sections. Section 2 shows database and methodology. In section 3, we have shown number of enterprises and other important characteristics across different activities in 2010-11 and 2015-16. Section 4 discusses the employment and labour productivity across enterprises. Section 5 analyses the status of growth of enterprises by multinomial logit model and find out the factors account for it. Section 6 concludes.

\section{Database and Methodology}

Present study is based on unit level data of National Sample Survey Organization (NSSO) 67 $7^{\text {th }}$ Round (201011) and $73^{\text {rd }}$ Round (2015-16) Survey on Unincorporated Non-Agricultural Enterprises (Excluding Construction) in India.

\section{Multinomial Logit Model}

The multinomial logit (MNL) model is used when all the regressors are case specific, the MNL model specifies that,

$$
P_{i j}=\frac{\exp \left(x_{i}^{\prime} \beta_{i}\right)}{\sum_{i=1}^{m} \exp \left(x_{i}^{\prime} \beta_{i}\right)}
$$

Where $X_{i}$ are case-specific regressors, which includes an intercept and characteristics of UFPEs. Clearly, this model ensures that $0<P_{i j}<1$ and $\sum_{j=1}^{m} P_{i j}=1$. To ensure model identification $\beta_{j}$ is set to zero for one of the categories, and coefficients are then interpreted with respect to that category called the base category.

Coefficient in a multinomial model can be interpreted in the same way as the parameters of binary logit model are interpreted, i.e., comparison being to the base category. This is a result of the multinomial logit model being equivalent to a series of pair wise logit models. For simplicity, we set the base category to be the first category. Then the MNL model defined implies that,

$$
\operatorname{Pr}\left(y_{i}=j \backslash y_{i}=j \text { or } 1\right)=\frac{\operatorname{Pr}\left(y_{i}=j\right)}{\operatorname{Pr}\left(y_{i}=j\right)+\operatorname{Pr}\left(y_{i}=1\right)}=\frac{\exp \left(x_{i}^{\prime} \beta_{i}\right)}{1+\exp \left(x_{i}^{\prime} \beta_{i}\right)}
$$

Using $\beta_{j}=0$ and cancellation of $\sum_{i=1}^{m} \exp \left(x_{i}^{\prime} \beta_{i}\right)$ in the numerator and denominator.
Thus, $\hat{\beta}_{t}$ can be viewed as parameters of binary logit model between alternative $j$ and alternative 1 . So, a positive coefficient of $m$-logit means that as the regressor increases, we are more likely to choose alternative $j$ than alternative1. This interpretation will vary with the base category and is clearly most useful when there is a natural base category. Some researchers find it helpful to transform to odds ratios or relative-risk ratios, as in the binary logit case. The odds ratio or relative-risk ratio of choosing alternative $j$ rather than alternative 1 is given by,

$$
\frac{\operatorname{Pr}\left(y_{i}=j\right)}{\operatorname{Pr}\left(y_{i}=1\right)}=\exp \left(x_{i}^{\prime} \beta_{i}\right)
$$

So, $e^{\beta_{j r}}$ gives the proportionate change in the relative risk of choosing alternative $j$ rather than alternative 1 when $x_{i r}$.

\section{RESULTS AND DISCUSSION}

\section{Structure of Unorganised Food Processing Enterprises}

According to National Industrial Classification (NIC), food processing enterprises can be divided into eight activities namely, animal, dairy, fish, meat, mill, oil, vegetable and other products. Total number of unorganised food processing enterprises (UFPEs) increased by 2,44,103 from 2010-11 to 2015-16 in India. More than 50\% UFPEs of total UFPEs were mill product enterprises (Fig. 1). These mill products enterprises include milling of flour, rice, dal, vegetables and other grains. The increment in meat product enterprises was highest while oil and vegetable products enterprises reduced during the period 2010-11 to 2015-16. The number of enterprises increased in all activities except oil and vegetable product during the study period (Table 1).

National Sample Survey Organisation (NSSO) has classified enterprises in two types: own account enterprises (OAE) and establishment enterprises (EST). The OAEs do not hire workers from outside whereas EST type enterprises hire workers from outside. Table 2 reveals that around 80\% UFPEs enterprises were 
Table 1: Number of unorganised food processing enterprises (UFPEs) in India, 2010-11 and 2015-16

\begin{tabular}{|c|c|c|c|c|c|c|}
\hline \multirow{2}{*}{ Activities } & \multicolumn{2}{|c|}{ Rural } & \multicolumn{2}{|c|}{ Urban } & \multicolumn{2}{|c|}{ Total } \\
\hline & 2010-11 & $2015-16$ & 2010-11 & $2015-16$ & 2010-11 & 2015-16 \\
\hline Animal Feeds & 1836 & 2917 & 3817 & 2881 & 5654 & 5798 \\
\hline Dairy Product & 36715 & 56006 & 32763 & 25203 & 69478 & 81209 \\
\hline Processing of Meat & 139284 & 251693 & 121979 & 186979 & 261263 & 438672 \\
\hline Grain Mill & 907620 & 904884 & 230438 & 244919 & 1138058 & 1149803 \\
\hline Other & 237478 & 229159 & 252658 & 307266 & 490137 & 536425 \\
\hline Total & 1361601 & 1472848 & 668693 & 801553 & 2030298 & 2274401 \\
\hline
\end{tabular}

Source: Authors' own calculation based on NSSO Unit Level data of 2010-11 and 2015-16.
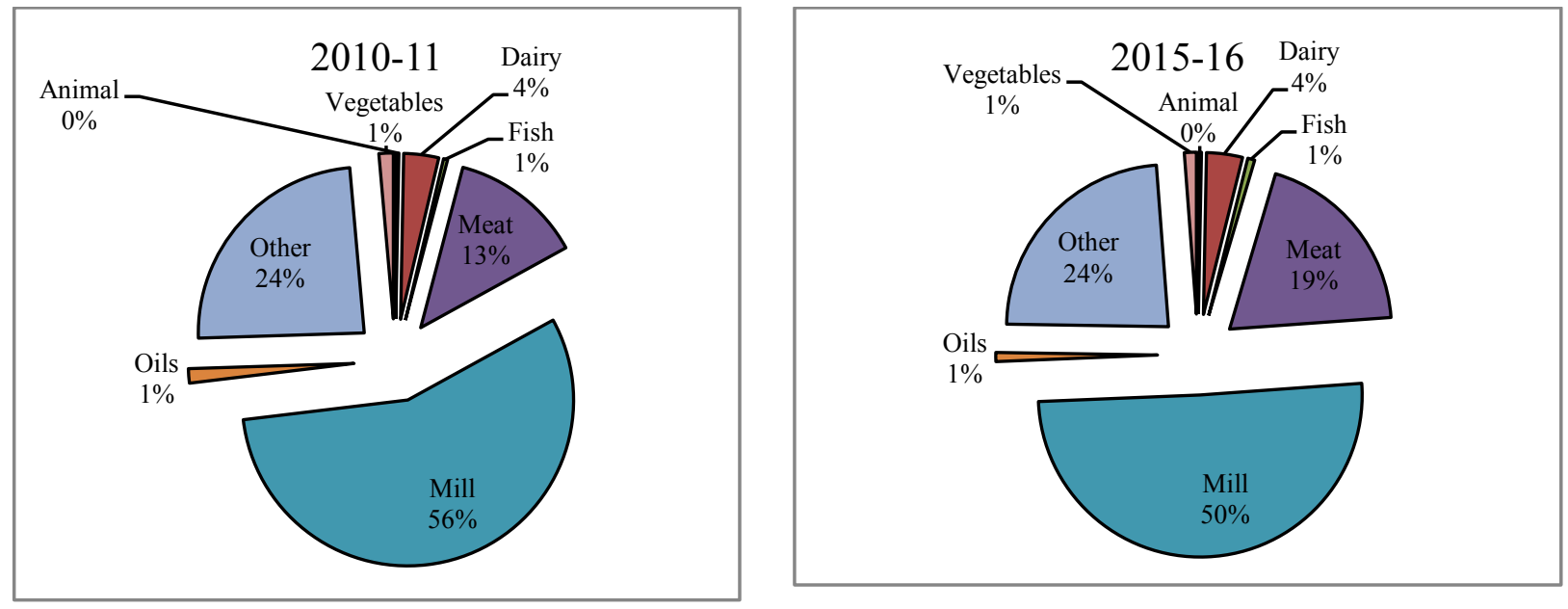

Fig. 1: Share of UFPEs across activities, 2010-11 and 2015-16

OAEs type in India. The share of OAEs were highest in fish product enterprises. From 2010-11 to 201516, the share of EST type enterprises reduced in all type of enterprises except oil and vegetables product enterprises. An enterprise may be registered in different type of acts. These are namely shops and establishment act, local body act, VAT or sales tax act, provident fund act, employees' state insurance act. Also, an enterprise may be registered under different types of authorities like State Directorate of Industries, Khadi \& Village industries board, State Financial Corporation, Small Industries Development Bank of India, District Supply and Marketing Society and so on. These types of acts directly or indirectly help an enterprise to conduct their business. It is found that around 30\% enterprises were registered in both the study periods. It means that most of the enterprises were outside registration under any act or institutions. The percentage of registered enterprises reduced in all activities except meat, oil and vegetable product enterprises. The percentage of registered enterprises fall drastically in animal, fish product enterprises. In 2010-11, 49.1\% animal product enterprises were registered but it reduced to only $14.2 \%$ in 2015-16.

The percentage of registered fish product enterprises was $51.3 \%$ in $2010-11$ which drastically reduced to $17.4 \%$ in 2015-16 (Fig. 2). Contrasting is another important indicator. An enterprise may go to an agreement with any other unit. The unit may supply raw materials, technology, design, plant and machinery. Type of contract may be of three types: (1) working solely for the parent unit, (ii) mainly for customers but also on 
Table 2: Share of UFPEs by types and percentage of registered enterprises, 2010-11 and 2015-16

\begin{tabular}{|c|c|c|c|c|c|c|c|c|}
\hline \multirow{2}{*}{ Activities } & \multicolumn{2}{|c|}{ OAE } & \multicolumn{2}{|c|}{ EST } & \multicolumn{2}{|c|}{$\%$ of Registered } & \multicolumn{2}{|c|}{$\%$ of Contracting } \\
\hline & $2010-11$ & 2015-16 & 2010-11 & $2015-16$ & 2010-11 & $2015-16$ & 2010-11 & $2015-16$ \\
\hline Animal Feeds & 50.5 & 59.7 & 49.5 & 40.3 & 49.1 & 14.2 & 0.23 & 0.47 \\
\hline Dairy Product & 72.4 & 79.5 & 27.6 & 20.5 & 18.8 & 15.5 & 1.8 & 2.57 \\
\hline Processing of Fish & 73.4 & 92.1 & 26.6 & 7.9 & 51.3 & 17.4 & 2.25 & 34.16 \\
\hline Processing of Meat & 78.6 & 78.8 & 21.4 & 21.2 & 37.4 & 46.5 & 0.49 & 7.98 \\
\hline Grain Mill & 85.7 & 87.5 & 14.3 & 12.5 & 26.8 & 26.2 & 0.32 & 1.42 \\
\hline Edible Oil & 66.8 & 58.9 & 33.2 & 41.1 & 37.2 & 42.7 & 0.42 & 1.03 \\
\hline Processing of Fruits \&Vegetables & 78.4 & 67.8 & 21.6 & 32.2 & 19.7 & 28.6 & 1.41 & 14.42 \\
\hline Other & 61.4 & 62.5 & 38.6 & 37.5 & 30 & 27.9 & 5.92 & 9.33 \\
\hline Total & 78 & 79.1 & 22 & 20.9 & 28.9 & 30.2 & 1.77 & 4.97 \\
\hline
\end{tabular}

Source: Authors' own calculation based on NSSO Unit Level data of 2010-11 and 2015-16.

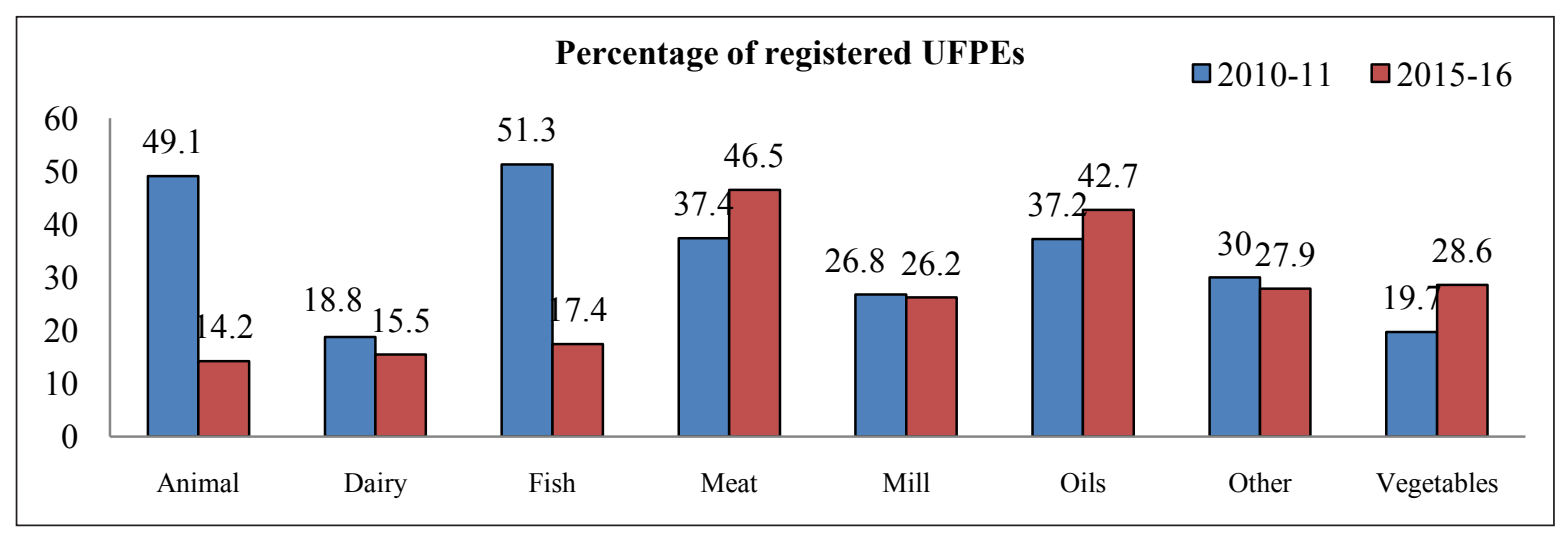

Source: Authors' own calculation based on NSSO Unit Level data of 2010-11 and 2015-16

Fig. 2: Percentage share of registered UFPEs across activities, 2010-11 and 2015-16

contract and (iii) mainly on contract but also for the customers. We can say that contracting with other unit should create a prior demand of the product. However, it is found that only $1.77 \%$ UFPEs were in contracting in $2010-11$ which significantly increased to $4.97 \%$ in 2015 16. The percentage of contracting enterprises almost doubled for all the activities. Moreover, the percentage of contracting enterprises significantly increased for fish, meat and vegetable product enterprises.

\section{Labour Productivity and Growth Status of UFPEs}

The ranking of activities in terms of employment were mill product, other product, meat product, dairy product, vegetable product, oil product, fish product and animal product in 2010-11 and 2015-16. The number of total employed workers increased by $3,47,000$ during the study period but the number of workers reduced in animal product, mill product and oil product. There were more than $50 \%$ rural workers in all the activities except animal, oil and other product activities. Largest rural workers involved in mill product enterprises. Mill and other product enterprises solely generated around $50 \%$ employment. The other enterprises in descending order of employment generation were meat, dairy, vegetable, oil, fish and animal product enterprises in 2010-11 and 2015-16. In all activities, new employment opportunity generated except animal, mill, and oil product enterprises.

Productivity is the most important indicator of a firm. There are many popular production functions to measure productivity. Here, productivity is measured by ratio of GVA to workers. In 2010-11, labour productivity of UFPEs in India was ₹ 47,047 which significantly increased to ₹ 77,186 in 2015-16. Labour productivity 
Table 3: Number of workers ('000) in UFPEs in India, 2010-11 and 2015-16

\begin{tabular}{lllll}
\hline \multirow{2}{*}{ Activities } & \multicolumn{2}{c}{ Rural + Urban } & \multicolumn{2}{c}{ \% share of rural workers } \\
\cline { 2 - 5 } & $\mathbf{2 0 1 0 - 1 1}$ & $\mathbf{2 0 1 5 - 1 6}$ & $\mathbf{2 0 1 0 - 1 1}$ & $\mathbf{2 0 1 5 - 1 6}$ \\
\hline Animal Feeds & 21 & 14 & 51 & 59 \\
Dairy Product & 161 & 177 & 52 & 59 \\
Processing of Fish & 32 & 42 & 717 & 56 \\
Processing of Meat & 460 & 1977 & 74 & 76 \\
Grain Mill & 1981 & 45 & 62 & 38 \\
Edible Oil & 71 & 1715 & 51 & 42 \\
Other & 1618 & 79 & 52 & 57 \\
Processing of Fruits \&Vegetables & 77 & 51 & 42 \\
Other & 1618 & 4420 & 4767 & 59 \\
\hline Total & & & \\
\hline
\end{tabular}

Source: Authors' own calculation based on NSSO Unit Level data of 2010-11 and 2015-16.

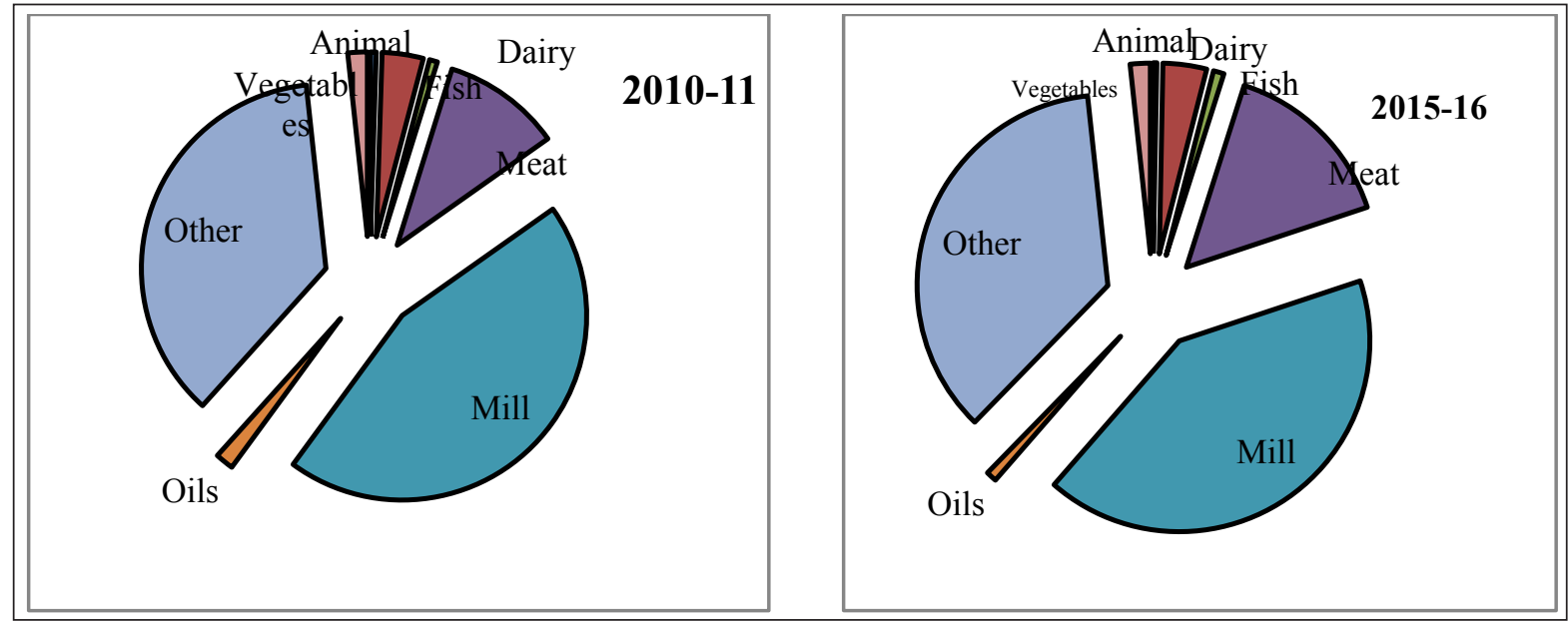

Source: Authors' own calculation based on NSSO Unit Level data of 2010-11 and 2015-16

Fig. 3: Share of workers across activities, 2010-11 and 2015-16

increased almost 1.5 times (Table 4). Labour productivity of urban enterprises was around two times higher than its rural counterpart in India for both the study periods. The labour productivity of all types of enterprises was higher in urban located enterprises except animal products and vegetable products enterprises. The animal product, fish product and oil product enterprises were most labour productive.

\section{Multinomial logit regression of growth status of UFPEs}

NSSO have classified the growth status of agro processing enterprises in three categories which are expanding, stagnating and contracting based on the last three years performance of a particular enterprise. Thus, growth status (STGR) is multinomial in nature. To analyse the status of growth we have used multinomial logit model. We have assigned the values 1 for expanding, 2 for stagnating, and 3 for contracting enterprises. We have excluded those firms which did not specify their status of growth status. Table 5 explains the notations, specifications and summary statistics of the variables used in the regression model. By using multinomial logit model, we explain the status of growth of UFPEs. In the model we have considered the status of growth as a dependent variable. UFPEs are facing three choices 
Table 4: Labour Productivity (₹) in UFPEs in India, 2010-11 and 2015-16

\begin{tabular}{lllllll}
\hline \multirow{2}{*}{ Activities } & \multicolumn{2}{c}{$\mathbf{2 0 1 0 - 1 1}$} & \multicolumn{2}{c}{$\mathbf{2 0 1 5 - 1 6}$} \\
\cline { 2 - 6 } & Rural & Urban & Total & Rural & Urban & Total \\
\hline Animal Feeds & 100761 & 64740 & 82946 & 173067 & 99184 & 135344 \\
Dairy Product & 40994 & 58190 & 49316 & 59313 & 96841 & 74642 \\
Processing of Fish & 58460 & 132267 & 71398 & 39625 & 76915 & 52207 \\
Processing of Meat & 60987 & 95283 & 80296 & 89502 & 147881 & 117700 \\
Grain Mill & 32950 & 59055 & 38584 & 47671 & 95432 & 59244 \\
Edible Oil & 52707 & 70095 & 59258 & 79645 & 125039 & 107574 \\
Processing of Fruits \& Vegetables & 48534 & 37468 & 43178 & 104303 & 71241 & 90229 \\
Other & 28741 & 65012 & 46447 & 56321 & 97156 & 79916 \\
\hline Total & 34990 & 67608 & 47047 & 57251 & 105449 & 77186 \\
\hline
\end{tabular}

Source: Authors' own calculation based on NSSO Unit Level data of 2010-11 and 2015-16.

Table 5: Notation, Specification and Summary Statistics of Variables used in the regression Model

\begin{tabular}{|c|c|c|c|}
\hline Notation & Specification & Average & SD \\
\hline \multicolumn{4}{|c|}{ Dependent variable } \\
\hline STGR & Status of growth is categorized as 1 if expanding, 2 if stagnating, 3 if contracting & $2.73(2.53)$ & $2.64(2.41)$ \\
\hline \multicolumn{4}{|c|}{ Independent variables } \\
\hline EST & Nature of enterprises: Whether the enterprise is establishment or not $(\mathrm{Yes}=1, \mathrm{No}=0)$ & $0.67(0.52)$ & $0.48(0.49)$ \\
\hline LOCATION & Location of enterprises: Whether the enterprise is urban located or not $\left(Y e s=1, N_{0}=0\right)$ & $0.60(0.59)$ & $0.49(0.49)$ \\
\hline NATOP & Nature of operation: Whether the enterprise is perennial or not $(\mathrm{Yes}=1, \mathrm{No}=0)$ & $1.04(1.03)$ & $0.22(0.20)$ \\
\hline GOVASST & $\begin{array}{l}\text { Government assistance: Whether the enterprise receives government assistance or not (Yes } \\
=1, \mathrm{No}=0)\end{array}$ & $1.98(1.99)$ & $0.12(0.97)$ \\
\hline ACCT & Account Maintain: Whether the enterprise maintain accountant or not $\left(\right.$ Yes $\left.=1, \mathrm{No}_{0}=0\right)$ & $1.91(1.87)$ & $0.28(0.33)$ \\
\hline REG & Registration: Whether the enterprise registered under act or not $(\mathrm{Yes}=1, \mathrm{No}=0)$ & $1.61(1.54)$ & $0.48(0.49)$ \\
\hline CONT & $\begin{array}{l}\text { Contracting: Whether the enterprise making contract with other parent entity or not (Yes = } \\
1, \mathrm{No}=0)\end{array}$ & $1.98(1.97)$ & $0.11(0.16)$ \\
\hline LOAN & The volume of credit accessed by the enterprise or not $(Y e s=1$, No $=0)$ & $0.92(0.90)$ & $0.27(0.28)$ \\
\hline SZFARM & Size of the firm is measured by the volume of fixed asset (in ₹ lakh) & $7.04(3.94)$ & $8.75(3.64)$ \\
\hline PROFT & $\begin{array}{l}\text { Profitability (in ₹. '000) of an enterprise is measured by the ratio of net profit to total } \\
\text { number of labour of an enterprise. }\end{array}$ & $3.59(65.36)$ & $3.50(73.3)$ \\
\hline
\end{tabular}

Values in parentheses denote 2015-16.

Source: Authors' own calculation based on NSSO Unit Level data of $67^{\text {th }}$ Round and $73^{\text {rd }}$ Round.

expanding, stagnating, and contracting which are coded as 1, 2, and 3. It is assumed that we have a set of observations $Y_{i}$, for $i=1,2, \ldots . ., m$, of the outcomes of multi-way choices from a categorical distribution of size $m=3$.

Along with $Y_{i^{\prime}}$ there are a set of $k$ observed values $x_{1, i^{\prime}}$ $\ldots, x_{k, i}$ of explanatory variables specifically nature of enterprise (EST), location of enterprise (LOCATION), nature of operation (NATOP), government assistance
(GOVASST), accountant maintenance (ACCT), registration of the enterprise (REGISTERED), enterprise in contract (CONT), access of loan (LOAN), size of the firm (SZFARM) and profitability (PROFT).

The results of multinomial logit model for the years 201011 and 2015-16 are shown in table 6. The growth status is significantly explained by nature of enterprise (EST), nature of operation (NATOP), accountant maintenance (ACCT), access of loan (LOAN) and profitability (PROFT) 
Table 6: Result of Multinomial Logistic Regression

\begin{tabular}{|c|c|c|c|c|c|c|}
\hline \multicolumn{4}{|c|}{ Regression Results for the year 2010-11 } & \multicolumn{3}{|c|}{ Regression Results for the year 2015-16 } \\
\hline \multicolumn{4}{|c|}{ Number of observations = 16834} & \multicolumn{3}{|c|}{ Number of observations $=14352$} \\
\hline \multicolumn{4}{|c|}{$\operatorname{LR} \chi^{2}(33)=1629.64$} & \multicolumn{3}{|c|}{$\operatorname{LR} \chi^{2}(33)=1589.57$} \\
\hline \multicolumn{4}{|c|}{ Prob. $>\chi^{2}=0.000$} & \multicolumn{3}{|c|}{ Prob. $>\chi^{2}=0.000$} \\
\hline \multicolumn{4}{|c|}{ Pseudo R2 = 0.0394} & \multicolumn{3}{|c|}{ Pseudo R2 = 0.0461} \\
\hline \multicolumn{4}{|c|}{ Log likelihood $=-19854.155$} & \multicolumn{3}{|c|}{ Log likelihood $=-16428.031$} \\
\hline STGR & Coef. & z-statistics & $P$ values & Coef. & z-statistics & P values \\
\hline \multicolumn{7}{|c|}{ Expanding $(=1)$ (base outcome) } \\
\hline \multicolumn{7}{|c|}{ Stagnating $(=2)$} \\
\hline EST & 0.514 & 12.79 & 0.000 & 0.518 & 12.3 & 0.000 \\
\hline LOCATION & 0.006 & 0.15 & 0.878 & -0.018 & -0.45 & 0.650 \\
\hline NATOP & 0.156 & 1.73 & 0.084 & 0.424 & 3.96 & 0.000 \\
\hline GOVASST & -0.027 & -0.15 & 0.879 & 0.150 & 0.72 & 0.475 \\
\hline ACCT & 0.360 & 5.24 & 0.000 & 0.340 & 5.64 & 0.000 \\
\hline REG & 0.045 & 1.1 & 0.269 & 0.060 & 1.5 & 0.134 \\
\hline CONT & -0.255 & -1.4 & 0.161 & -0.020 & -0.17 & 0.867 \\
\hline LOAN & 0.285 & 3.85 & 0.000 & 0.141 & 1.99 & 0.046 \\
\hline SZFARM & 0.001 & 1.03 & 0.304 & -0.001 & -0.67 & 0.504 \\
\hline PROFT & -0.007 & -11.34 & 0.000 & -0.181 & -5.78 & 0.000 \\
\hline Constant & -0.717 & -1.45 & 0.147 & -1.690 & -3.46 & 0.001 \\
\hline \multicolumn{7}{|l|}{ Contracting $(=3)$} \\
\hline EST & 0.740 & 10.78 & 0.000 & 0.683 & 9.56 & 0.000 \\
\hline LOCATION & -0.120 & -1.86 & 0.062 & -0.190 & -2.8 & 0.005 \\
\hline PERENNIAL & 0.619 & 5.06 & 0.000 & 0.375 & 2.4 & 0.017 \\
\hline GOVASST & 0.460 & 1.46 & 0.143 & -0.162 & -0.54 & 0.592 \\
\hline $\mathrm{ACCT}$ & 0.392 & 3.29 & 0.001 & 0.530 & 4.98 & 0.000 \\
\hline REG & -0.200 & -2.99 & 0.003 & -0.208 & -2.98 & 0.003 \\
\hline CONT & 0.207 & 0.61 & 0.541 & 0.073 & 0.39 & 0.693 \\
\hline LOAN & -0.025 & -0.21 & 0.83 & 0.171 & 1.49 & 0.137 \\
\hline SZFARM & 0.002 & 1.18 & 0.238 & 0.006 & 3.39 & 0.001 \\
\hline PROFT & -0.175 & -12.77 & 0.000 & -0.006 & -8.54 & 0.000 \\
\hline Constant & -4.424 & -4.85 & 0.000 & -3.450 & -4.73 & 0.000 \\
\hline
\end{tabular}

Source: Authors' own calculation based on NSSO Unit Level data of $67^{\text {th }}$ Round and $73^{\text {rd }}$ Round.

in 2010-11 as well as in 2015-16. The establishment type enterprises compared to own account enterprises are more likely expanding than stagnating and contracting. Perennial enterprises compared to seasonal and casual enterprises are more likely expanding than stagnating and contracting. The enterprises who maintain their account are more likely expanding than stagnating and contracting. The enterprises having access to loan are more likely expanding than stagnating and contracting. Also, highly profitable UFPEs are more likely expanding than stagnating and contracting.

\section{CONCLUSION}

The number as well as the employment in unorganised food processing enterprises (UFPEs) increased significantly during $2010-11$ to $2015-16$. More than $50 \%$ 
of total UFPEs were grain mill product enterprises. The number of enterprises increased in all activities except edible oil and processing of fruits \&vegetable product during the study period. The percentage share of OAEs was higher than that of the establishment enterprises across activities of UFPEs. It was predominately high in processing of fish product enterprises. The registered enterprises fall drastically in case of animal feeds, processing of fish product enterprises. Although, less than $2 \%$ UFPEs did business in contract with other parent enterprise but the important point is that the percentage of contracting enterprises almost doubled during the study period. The largest share of rural workers was found in grain mill product enterprises. The labour productivity of UFPEs increased almost 1.5 times in India during 2010-11 to 2015-16. Animal feeds product, processing of fish product and edible oil product enterprises were most labour productive. Whereas the labour productivity of urban located UFPEs was higher than its rural counterpart except animal feed products and fruits \& vegetable product enterprises. The analysis of growth status shows that establishment type and perennial nature of enterprises were more likely to be expanding than stagnating and contracting. Also, availability of loan and accountant maintenance significantly affects the expanding nature of an enterprise. Moreover, highly profitable UFPEs were more likely to be expanding than stagnating and contracting.

\section{REFERENCES}

Dhanya, V. et al. 2020. Food Processing Industry in India: Challenges and Potential. RBI Bulletin, pp. 27-41.

Paramasivan, C. and Pasupathi, R. 2016. Performance of Agro Based Industries in India. National Journal of Advanced Research, 2(6): 25-28.

Venkatesh et al. 2017. Agro-Processing Industry and Farmers' Linkages: Pattern and Impact on Enhancing Farmers' Income in Tamil Nadu. Agricultural Economics Research Review, 30: 1325

Dhiman, P. and Rani, A. 2011. Problems and Prospects of Small Scale Agro Based Industries: An Analysis of Patiala District. International Journal of Multidisciplinary Research, 1(4): 129-142.

Kaur, N. and Kaur, K. 2016. Efficiency, Productivity and Profitability Changes in the Indian Food Processing Industry: A Firm Level Analysis. Pacific Business Review International, 1(1): 264-272.

Rais, M. et al. 2013. Food Processing Industry in India: S\&T Capability, Skills and Employment Opportunities. Journal of Rural Development, 32(4): 451-478.

Bhosale R.V. 2016. Agro-Based Processing Industries in Rural Development in India. MIT- SOM PGRC KJIMRP National Research Conference. Special Issue, pp. 234-240.

Mohan M.S. and Jayachandra, K. 2018. Marketing Problems of Agro Based Industries in Andhar Pradesh: With Special Reference to Chittoor District. International Journal of Advance Research and Innovative Ideas in Education, 4(1): 42-47.

Rais, M. et al. 2014. Food Processing Industry: Opportunities in North East Region of India. The NEHU Journal, 12(1): 37-51. 
